\title{
Longitudinal study of removable partial dentures and hygiene habits
}

\section{Estudo longitudinal de próteses parciais removíveis e hábitos de higiene}

\author{
Mateus Bertolini Fernandes dos SANTOS \\ Undergraduate Student - São José dos Campos Dental School - UNESP - São Paulo State University - São José dos \\ Campos - SP - Brazil
}

\author{
Renata Marques de CARVALHO \\ Tatiana Suckow da Silva Camargo GUIMARÃES \\ Undergraduate Student - University of Vale do Paraiba - UNIVAP - São José dos Campos - SP - Brazil
}

\author{
Jarbas Francisco Fernandes dos SANTOS \\ Graduate Student - São José dos Campos Dental School - UNESP - São Paulo State University - São José dos Campos - \\ SP - Brazil \\ Assistant Professor - University of Vale do Paraiba - UNIVAP - São José dos Campos - SP - Brazil - University of \\ Taubaté - UNITAU - Taubaté - SP - Brazil
}

\section{Leonardo MARCHINI}

Assistant Professor - University of Vale do Paraiba - UNIVAP - São José dos Campos - SP - Brazil - University of Taubaté - UNITAU - Taubaté - SP - Brazil

\section{SUMMARY}

The removable partial dentures (RPD) are used to reestablish the phonetics, aesthetics and masticatory function for partially dentate patients, mainly those who compound the Brazilian poorest population, since RPD presents a relatively low cost. The rehabilitation gone to be successfully when besides the planning, the dentist orientate hygiene habits to the patient, and proserve the case. The present paper evaluates hygiene habits and RPD planning among a sample of RPD wearers, in a cross-sectional design. A questionnaire was applied and a clinical examination was performed by two previously calibrated examiners. The sample was composed by 83 patients, and 25 were males. It was verified that $49.4 \%$ of the patients brush their teeth three times per day and that $28.9 \%$ took approximately 4 minutes for each teeth brushing, $95.2 \%$ use other hygiene resources, besides toothbrushing, as dental cream (98.7\%), dental floss (79.7\%) and mouthrinses $(55.7 \%)$. However $56.6 \%$ showed bacterial plaque and $21.7 \%$ presented caries at clinical exam. About the dentures, $74.7 \%$ was definitive RPD and $96.4 \%$ showed bilateral design. The requisites of stability, retention, occlusion and aesthetics was classified as good, in the majority of the cases; the hygiene was classified as good to regular. In $24 \%$ of the dentures, the base was deformed or fractured, 50.6\% presented artificial teeth with detritions. Instead of patients' adequate oral hygiene habits and satisfaction with RPD, more comprehensive explanations about oral care and more frequent follow-ups should be considered to improve plaque index and periodontal health among RPD wearers.

\section{UNITERMS}

Removable partial dentures; oral hygiene. 


\section{INTRODUCTION}

Removable partial dentures (RPD) are the cheapest way for prosthetic rehabilitation; it is known that RPD is generally indicated for the people with low income ${ }^{10}$. Therefore RPD are considered non-aesthetic and some authors have related that they should damage the reminiscent oral structures ${ }^{12}$.

The dentures just cause damage to the sthomatognatic system when the biomechanical principles of support, retention and stability were not observed and when the clinical and/or laboratorial steps for RPD making are neglected, resulting in poor adaptation ${ }^{4,9}$.

During RPD planning, the expectations of the patient should be also considered, mainly regarding RPD aesthetics. If the dentists do not observe the individual necessities, the treatment should be unsuccessful ${ }^{6}$.

RPD failures are consequences of destructive action of bad designed device, due to the apparent simplicity and facility of it manufacturing ${ }^{10}$. Many dentists have no attention with planning and delegate it to dental technicians. Analyzing casts on dental laboratories, Duarte \& Paiva (2000) observed that majority of them did not present adequate teeth preparation, as rest niches, teeth re-contour, or guide planes ${ }^{3}$. Dental technicians have a key role in the success of RPD. However, they do not have adequate knowledge of the biological structures and occlusion, which is need to well distribute masticatory forces adequately. Then, RPD should be designed and planned by dentists. Nevertheless, it was shown that just $10 \%$ of the cases that come to laboratory presented teeth preparations, and less than $25 \%$ of the dentists verified RPD waxing, neglecting the process and then allowing technical failures ${ }^{5}$.

Other factor that was presented as relevant to RPD longevity is the establishment of correct hygiene program and follow-up. The importance of hygiene should be emphasized, because majority of these patients lost their teeth due to an absence of explanation or motivation for dental hygiene habits ${ }^{4}$. When patients are conscious of the plaque pathogenicity, they are able to practice the hygiene methods to remove it $^{1}$.

Evaluating 74 patients which wore 101 RPD, it was verified that only $36.6 \%$ was considered successful, $23.8 \%$ presented a score of partial success and $39.6 \%$ failed. Only a third part of the total did not show hygiene problems or technical failure, and 50\% of these dentures may expect 10 years of overtime ${ }^{11}$.

Considering the importance of planning and hygiene habits for RPD success and longevity, the present paper aims to evaluate these factors among a sample of RPD wearers from São José dos Campos, Brazil.

\section{Material AND METHOD}

\section{Subjects}

The sample was composed by 83 RPD wearers that come to UNIVAP dental clinics in the period from December 2003 to December 2004. All RPD wearers that did NOT want to change their dentures were invited to participate on the study.

The project of this research was approved by the pertinent ethical committee, according with the protocol number L032/2004/CEP, and the procedures were realized only after the free consent of the patients.

\section{Data collection}

A direct questionnaire was applied and a clinical examination was performed, in which periodontal analysis was realized based on Periodontal Diagnostic System $(\mathrm{PSR})^{2}$, realized during probing procedure with a recommended sounding lead (621 OMS), and the scores $0-4$, which identifies bleeding, dental calculus and periodontal pocket, were attributed to each sextant. All questionnaires and clinical exams were done by two previously calibrated examiners. The examiners interviewed the patients in agreement with the questionnaire, which asked about frequency of returns in a surgeon dentist, hygiene orientations received about the prosthesis and the opinion of their own prosthesis. During the clinical examination it was verified aspects like periodontal condition, analysis of hygiene, stability, retention, occlusion and aesthetics of the prosthesis. In relation of prosthetic planning it was verified the existence of rest prepare, distal extension, rest localization, fracture or deformation of any element of the prosthesis.

The obtained data were tabulated and statistically analyzed, using the Chi-square distribution for the independence on the verification of possible association of two variables and its levels.

\section{RESULTS}

\section{Descriptive analysis}

\section{Oral and denture hygiene habits}

It was analyzed 83 RPD wearers, from which 58 were females. It was observed that $33.7 \%$ of all sample return on the dentist for periodical examinations every six months (Graph 1).

Orientation for dentures hygiene was reported by 
$86.7 \%$ and $78.3 \%$ also reported orientation for oral cavity hygiene. $49.4 \%$ of the sample brush the teeth three times a day (Graph 2), and that $44.6 \%$ spent approximately two minutes doing it; $50.6 \%$ uses dental brush with soft bristles, and $69.9 \%$ change toothbrushes every three months.

The majority of argued patients (98.8\%) mentioned that they remove the dentures during teeth brushing and $95.2 \%$ affirmed that uses other hygiene methods, besides toothbrushing, mainly the use of dental cream (98.7\%).

RPD hygiene had a good classification in $43.4 \%$ of the cases (Graph 3).

\section{Denture planning}

Considering all sample, $62(74.7 \%)$ were definitive and $21(25.3 \%)$ provisory, and $80(96.4 \%)$ presented bilateral design, while only $3(3.6 \%)$ were unilateral RPD. In relation to definitive dentures, it was evidenced that $71 \%$ of the patients had rest niches, and $93.5 \%$ of the RPD presented rigid opposing arms. Considering dentures that were cantilevered, the rest on the main attachments teeth were located in the mesial on $81.7 \%$ (Graph 4), and $67.3 \%$ presented indirect rest.

In this sample, $24 \%$ of the dentures had basis deformation or basis fracture. Between the dentures components, the artificial teeth showed great number of problems, and teeth abrasion was encountered in $50.6 \%$ of the cases.

The dentures also were evaluated and classified by the examiners in good, regular or bad, in regard to their stability, retention, occlusion and aesthetics. Stability and retention had $50.6 \%$ of good classification, occlusion were considered regular in $33.7 \%$ of the dentures, and aesthetics received $38.6 \%$ of good classification, $36.1 \%$ regular and $25.3 \%$, bad.

Regarding the kind of dental service where the dentures have been realized, the predominance was in particular services (47\%).

During clinical exams, it was observed the existence of bacterial plaque in $56.6 \%$ of the individuals, and $78.3 \%$ had absence of active caries. At the periodontal exam (PSR) it was evidenced a minimal proportion of periodontal health $(0.8 \%)$.

In relation of patient satisfaction, $45.8 \%$ considered their dentures as regular to bad. Problems regarding stability were related by $50 \%$ of the sample, and lack of retention, by $47.4 \%$.

\section{Analysis of possible relationships among the variables}

Retention and stability presented an expressive positive relationship $(\mathrm{p}<0.001)$ with good classification.

Positive significance was also presented between bacterial plaque presence and bad periodontal condition for the sextants $\mathrm{S} 2(\mathrm{p}=0.003), \mathrm{S} 5(\mathrm{p}=0.003)$ and $\mathrm{S} 4(\mathrm{p}=0.051)$.

Occlusal problems and artificial teeth presented no relationship $(\mathrm{p}=0.113)$, since there was not an association between the classification of the occlusion as good, regular or bad and the presence of detritions or fracture of the artificial teeth.

It was also verified that the rest prepare was not related with caries ( $\mathrm{p}=0.404)$, because the majority of individuals that own rest prepare did not present caries. It was also noticed a lack of association $(\mathrm{p}=0.758)$ between the classification of hygiene level and the instruction level of the patients.

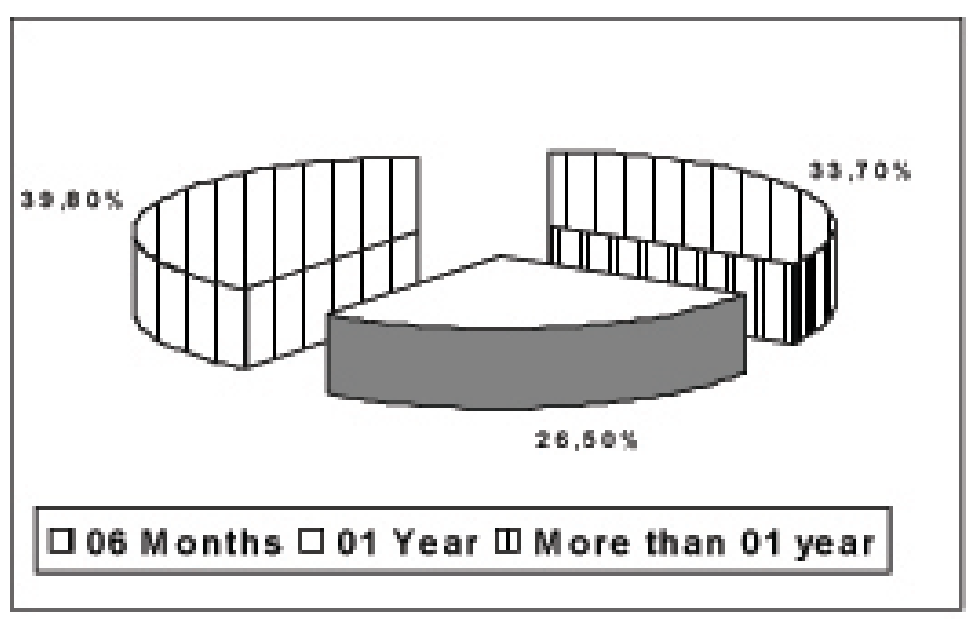

Graph 1. Periodical returns at dentist. 


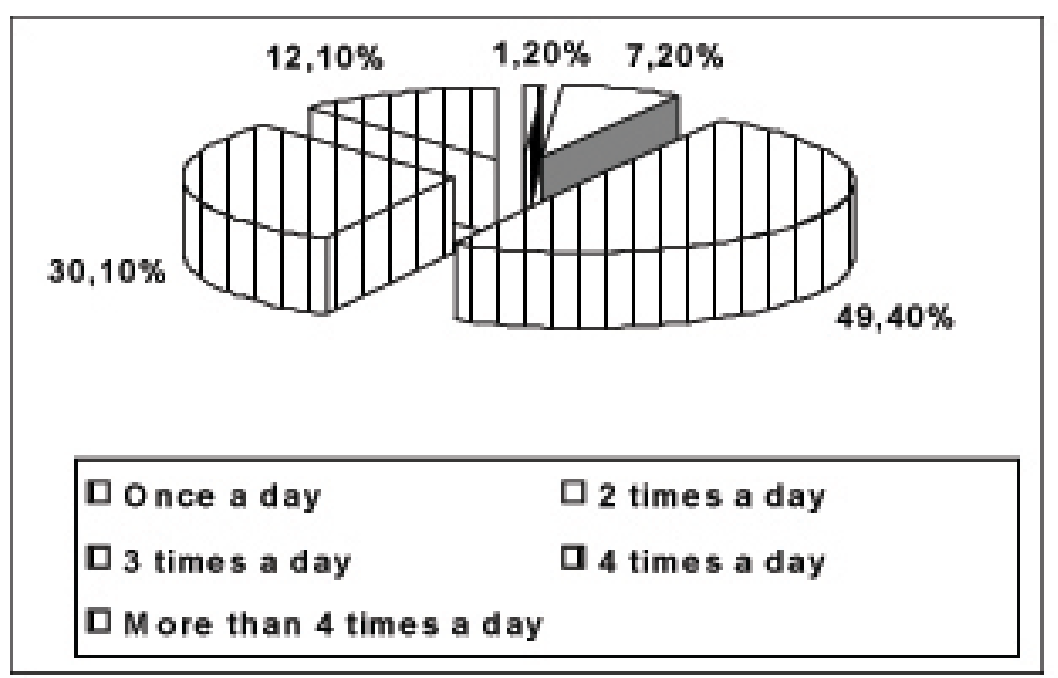

Graph 2. Brushing teeth frequency.

Graph 3. Hygiene classification.

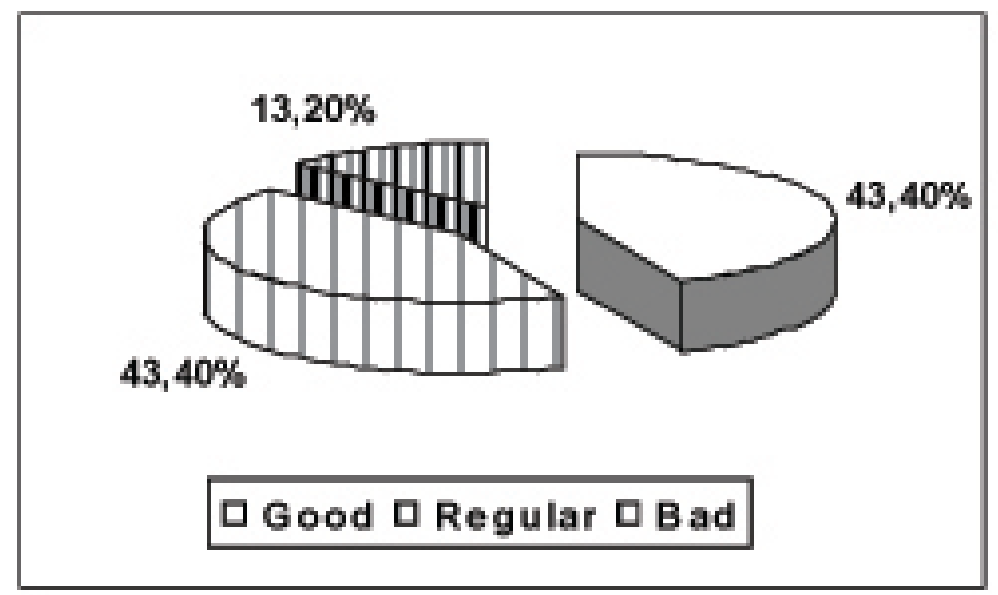

\section{Discussion}

According to Todescan $(1998)^{10}$, the edentulous individuals who seek for dental treatment generally present low level of hygiene habits, and this factor should be the most important causal factor for dental mutilation. However, $33.7 \%$ of our sample affirmed that visit periodically the dentist, the major portion of the sample $(79.5 \%)$ related that they brush the teeth three or four times a day and $95.2 \%$ also uses other hygiene methods besides toothbrushing, as dental cream $(98.7 \%)$ and dental floss $(79.7 \%)$.

For Öwall et al. (2002) $)^{7}$, during the confection of the RPD, the prevention and hygiene should be emphasized, although the literature is focused in biomechanical aspects. Todescan $(1998)^{10}$ stated that patients should be motivated for oral hygiene, in order to allow a higher longevity for RPD therapy. Regar- ding this issue, we observed that $86.7 \%$ of the sample received orientation for oral hygiene and $78.3 \%$ about the importance of dentures hygiene, but only $33.7 \%$ was oriented the way to adequate clean the dentures. This fact pinpoints failures in the process of oral hygiene learning, whose instruction and information depends on the dentist.

Regarding dentures planning, it was early verified that $87.2 \%$ of the dentures made by particular services were definitive and $93.6 \%$ of the dentures realized in dental institutions own rest prepare, while $6 \%$ of the dentures realized by a prosthetic technician do not own rest prepare, because they do not know about RPD biomechanics and planning rules ${ }^{3}$.

In $100 \%$ of the cases with free extremity realized in institutions, the rest were located in mesial, eviden- 


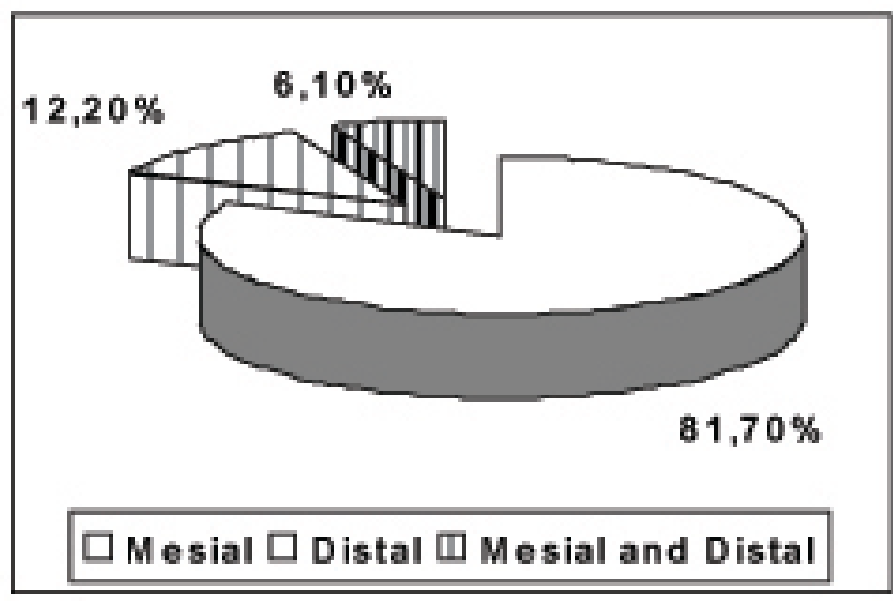

Graph 4. Rest localization in free extremity RPD.

cing a great control and orientation of dental students about planning (Graph 4). Still working with this kind of dentures $67.3 \%$ presented indirect rest, which is relevant to the success of the rehabilitation ${ }^{4}$.

Rest niches was observed in $71 \%$ of the cases, contrariwise of Matos $(2002)^{5}$, who affirmed that only $10 \%$ of casts received by dental laboratories presented adequate teeth preparations. It was not encountered a positive relation between rest niches and caries presence $(\mathrm{p}=0.404)$, opposing many dentists that do not realize rest niches by considering it a niche for plaque accumulation.

The incidence of failures in each component of RPD decrease by the following order: clasps, artificial teeth, basis, conectors ${ }^{8}$. The present paper observed that the failures incidence decrease from clasps $(14.5 \%)$ to connectors $(9.7 \%)$, but the basis presented the higher percentage of failures $(24 \%)$.

RPD were also analyzed regarding occlusion, and it was not observed direct relationship between occlusal factors and the presence of detritions of artificial teeth. However when retention and stability were analyzed, it was observed a positive relationship with good classification $(\mathrm{p}<0.001)$, showing that these factors are good predictors of RPD accepting by the patient.

The aesthetics, pointed by many individuals as more important than function ${ }^{6}$, were analyzed and classified as bad in $25.3 \%$ of the cases, fact that have a high negative impact in the patient satisfaction.
Wagner and Kern $(2000)^{11}$ showed that $90 \%$ of the sample of his study were satisfied with retention, and less than $80 \%$ with aesthetics. The present paper observed that even tough $54.2 \%$ of the patients consider their dentures as good, many aspects of planning and hygiene orientation were neglected, and many of them shown major problems as fracture $(44.7 \%)$, lack of retention (47.4\%) and stability (50\%).

Considering the importance of RPD in oral rehabilitation in Brazil, we think that more clinically based studies should be conducted on the issue of patient satisfaction and its related variables, in order to better fit the RPD based therapies to patients' necessities.

\section{Conclusion}

Considering the applied methodology, it should be highlighted that oral hygiene habits among RPD wearers are adequate, instead of a more comprehensive explanation about the topic should be made by dentists, to control plaque and periodontitis more effectively. Adequate planning was observed in majority of RPD and retention and stability seems to be a good predictor of RPD acceptance. Frequent follow-ups should be considered to prevent consequences of often observed basis changes and artificial tooth abrasion

\section{Resumo}


As próteses parciais removíveis (PPR) são usadas para restabelecer fonética, estética e função em pacientes parcialmente dentados, principalmente para aqueles que compõem a população pobre brasileira, visto que as PPR apresentam baixo custo de confecção. Para que a reabilitação seja bem sucedida, além do planejamento correto, orientações quanto à higiene bucal, das próteses e proservação do caso se fazem necessárias. O presente estudo avaliou hábitos de higiene e o planejamento das PPR de uma amostra de portadores de PPR, em estudo transversal. Para tanto foi utilizado questionário e exame clínico realizados por dois examinadores previamente calibrados. Foram analisados 83 pacientes, 25 do sexo masculino, verificou-se que 49,4\% dos pacientes escovavam os dentes três vezes ao dia e que 28,9\% levam cerca de 4 minutos para a escovação, 95,2\% usavam outros meios de higienização, além da escova, como: creme dental (98,7\%), fio dental (79,7\%) e colutórios $(55,7 \%)$. Porém, observou-se que 56,6\% apresentavam placa bacteriana e $21,7 \%$ cárie ao exame clínico. Quanto às próteses 74,7\% eram definitivas e 96,4\% eram bilaterais. Os requisitos de estabilidade, retenção, oclusão e estética foram classificados como bons, na maioria dos casos; já a higiene teve igual proporção para bom e regular. Em $24 \%$ das próteses, a base encontrava-se fraturada ou deformada, 50,6\% apresentavam os dentes artificiais com desgaste. Embora a maioria dos pacientes considerasse sua prótese boa, explicações mais completas sobre os cuidados orais e maior freqüência de visitas ao dentista devem ser considerados para melhorar a saúde periodontal e o controle de placa em usuários de PPR.

\section{UNITERMOS}

Prótese parcial removível; higiene oral.

\section{References}

1. Asckar EM, Vieira LF, Bonachela WC. Estudo longitudinal de pacientes portadores de próteses parciais removíveis (PPR) em relação aos dentes controles, retentores primários e retentores secundários com acompanhamento profissional. Odontologia USF. 1999; 17:63-77.

2. Conde MC, Saraiva MCP, Kon S, Todescan JH, Pustiglioni FE. Um método simplificado de diagnóstico periodontal. Rev Assoc Paul Cir Dent. 1996; 50(2):139-42.

3. Duarte C, Paiva H. Avaliação do nível de conhecimento e conscientização do cirurgião dentista e do técnico em prótese dental, em relação ao planejamento e a execução de próteses parciais removíveis - estudo laboratorial. Rev ABO Nac. 2000; 8(4):232-7.

4. Kliemann C, Oliveira W. Manual de prótese parcial removível. São Paulo: Santos; 1999.

5. Matos RL, Pagnano VO, Ribeiro RF, Mattos MGC. Avaliação da interação cirurgião dentista/ técnico no processo de confecção de prótese parcial removível. RPG Rev Pos Grad. 2002;9(1):63-9.

6. Mazurat NM, Mazurat RD. Discuss before fabricating: communicating the realities of partial denture therapy. Part II: clinical outcomes. J Can Dent Assoc. 2003; 69(2):96-100.

7. Owall B, Budtz-Jorgensen E, Davenport J, Mushimoto E, Palmqvist S, Renner R, et al. Removable partial denture design: a need to focus on hygienic principles? Int J Prosthodont. 2002;15(4);371-8.

8. Saito M, Notani K, Miura Y, Kawasaki T. Complications and failures in removable partial dentures: a clinical evaluation. J Oral Rehabil. 2002; 29(7):627-33.

9. Tamaki T. Prótese parcial fixa e removível. São Paulo: Sarvier; 1982.
10. Todescan R, Bernardes EEB, Silva OJ. Atlas de prótese parcial removível. São Paulo: Santos; 1998.

11. Wagner B, Kern M. Clinical evaluation of removable partial dentures 10 years after insertion: success rates, hygienic problems, and technical failures. Clin Oral Investig. 2000;4(2):74-80.

12. Walter JD. Planejamento de prótese parcial removível. São Paulo: Santos; 1991.
Recebido em: 03/02/07 Aprovado em: 10/08/07

Mateus Bertolini Fernandes dos Santos R. Eng 'o João Fonseca, 123 ap.34 SJCampos 12243-620, SP, Brazil mateusbertolini@yahoo.com.br Phone (55 12) 3913-2791 